\title{
Concrete Containing Palm Oil Fuel Ash (POFA) and Oil Palm Shell (OPS) Subjected to Elevated Temperatures
}

\author{
L.Y. Jong and D. C. L. Teo \\ Department of Civil Engineering, Faculty of Engineering, Universiti Malaysia Sarawak, 94300 Kota Samarahan, Sarawak, \\ Malaysia
}

Date Received: 4 November 2014

Date Published: 30 January 2015

\begin{abstract}
Nowadays, waste products such as Palm Oil Fuel Ash (POFA) and Oil Palm Shell (OPS) are produced in large quantities from the agriculture industry on a daily basis. Improper disposal of the agriculture wastes at landfills contributes to environmental pollution. The cost of construction material increases when the demand is high. Therefore, reutilization of these waste products not only reduces the cost of construction material but also minimizes waste disposal problem. In this research, waste POFA and OPS as cement and aggregate replacement respectively are used to produce a 'greener' concrete. This paper presents the effects of elevated temperatures on POFA OPS concrete. A concrete made from OPS aggregates (0\% POFA) was also produced as a comparison. From the results obtained, it was observed that the formation of hair-line cracks on the surface of POFA OPS concrete specimen was less visible than OPS concrete specimen. All concrete specimens experience mass loss after being subjected to elevated temperatures. In terms of compressive strength, both OPS concrete and POFA OPS concrete specimen experienced a decrease in strength after being subjected to elevated temperatures. However, the POFA OPS concrete specimen showed better strength performance as compared to OPS concrete specimen at elevated temperatures of $200^{\circ} \mathrm{C}$ to $500{ }^{\circ} \mathrm{C}$.
\end{abstract}

Keywords: POFA OPS, Elevated temperatures, Crack development, Mass loss, Compressive strength

\section{INTRODUCTION}

CONCRETE is used in buildings, bridges, dams tunnels, sewerage systems pavements, runways and even roads. However, the production of concrete consumes large amount of natural resources. Due to the increasing cost of raw materials and continuous depletion of natural resources, the use of waste materials is a potential alternative in the construction industry. The reuse of waste materials helps to save and sustain natural resources that cannot be replenished, decreases pollution to the environment and also helps to save and recycle energy production processes [1].

In Malaysia, palm oil industry is one of the largest agricultural industries. The accumulation of leftover agrowaste will cause land and air pollution in the vicinity of palm oil factories. Researchers have taken the initiative to utilize the palm oil wastes to develop sustainable construction materials [2-3]. Palm Oil Fuel Ash (POFA) contains high amount of silica that can react with calcium hydroxide $\left(\mathrm{Ca}(\mathrm{OH})_{2}\right)$ through hydration process and the pozzolanic reactions produce a lot of calcium silicate hydrate $(\mathrm{C}-\mathrm{S}-\mathrm{H})$ gel compound in order to reduce the amount of calcium hydroxide [4]. Hence, POFA can contribute to make stronger, denser and more durable concrete in concrete production. Concrete using OPS as coarse aggregate has been found very useful as structural lightweight concrete [5]. OPS is much lighter and has low bulk density compared to conventional stone aggregate. Consequently, the resulting OPS concrete becomes a lightweight concrete [5]. However, the study of concrete incorporating POFA and OPS as partial cement and coarse aggregate replacement respectively is still relatively new and only limited information is available. By integrating the POFA in OPS concrete, it would be an added benefit to construction industry as well as palm oil industry in terms of economic and environmental aspects.

Fire is one of the most destructive powers which can expose concrete to elevated temperatures and it is one of the major risks faced by building structures. The chemical composition and physical structure of concrete will be affected when concrete is subjected to elevated temperature. During elevated temperatures, the strength of Ordinary Portland Cement (OPC) concrete decreases due to chemical and physical changes [6]. In addition, spalling of concrete during fire will cause a rapid layer-by-layer loss of concrete cover and finally leading to the exposure of the main reinforcements within the concrete

Jong, L. Y is with the Department of Civil Engineering, Faculty of Engineering, Universiti Malaysia Sarawak, 94300 Kota Samarahan, Sarawak, Malaysia (e-mail: xnykira90@gmail.com).

Teo, D. C. L is with the Department of Civil Engineering, Faculty of Engineering, Universiti Malaysia Sarawak, 94300 Kota Samarahan, Sarawak, Malaysia (corresponding author, phone: 082-58 3273; e-mail: tdelsye@ feng.unimas.my). 
to the fire [7]. Elevated temperature has been found to have an effect on the concrete's characteristics such as compressive strength, elasticity, color, concrete density and surface appearance [8]. Hence, many researchers try to seek some solutions to improve the concrete's fire resistance. Recent studies have found that cement replacement with pozzolanic materials in the production of concrete is one of the efficient ways to improve the fire resistance of concrete [9-11].

In this paper, the effects of elevated temperatures on concrete containing both POFA and OPS, hereinafter called POFA OPS concrete were investigated. An OPS concrete specimen (0\% POFA) was also produced for comparison. Compressive strength, mass loss, and crack development of concrete specimens subjected to elevated temperatures were reported in this paper.

\section{MAterials}

The materials used in this research were Ordinary Portland cement (OPC) ASTM Type 1, POFA, OPS, and river sand for the production of concrete.

POFA was collected from a local oil palm mill. The freshly collected POFA was first dried in the oven at a temperature of $110 \pm 5^{\circ} \mathrm{C}$ for 24 hours to remove moisture in the POFA. Then, the POFA was sieved through a $300 \mu \mathrm{m}$ sieve to separate the larger particles and other impurities. Next, POFA was grounded in a Los Angelas abrasion test machine and the grounded POFA was sieved passing through a $45 \mu \mathrm{m}$ sieve. After that, the sieved POFA was further burnt using muffle furnace at a temperature of $700^{\circ} \mathrm{C}$ for 1 hour. It has been previously found that by burning Rice Husk (RH) at high temperatures for a certain duration can increase the silica content [12]. Therefore, a similar burning process was adopted on POFA in this study. The burnt POFA was kept in an airtight container separately to prevent the POFA from being exposed to moisture.

OPS used in this study was also obtained locally. The collected OPS was cleaned by water to remove the oil coating on the surface of the shell. Next, the cleaned OPS was dried under the sun. The OPS had a specific gravity of 1.34 and water absorption of $23 \%$. The OPS used for mixing concrete were under saturated surface dry (SSD) condition based on 24 hours submersion in potable water.

\section{EXPERIMENTAL PROCEDURES}

\section{A. Mix Proportions and Curing}

The POFA OPS concrete consists of $384 \mathrm{~kg} / \mathrm{m}^{3}$ cement, $96 \mathrm{~kg} / \mathrm{m}^{3}$ POFA ( $20 \%$ by weight of cement replacement), 192 $\mathrm{kg} / \mathrm{m}^{3}$ water, $362 \mathrm{~kg} / \mathrm{m}^{3}$ OPS and $821 \mathrm{~kg} / \mathrm{m}^{3}$ river sand with water to binder ratio of 0.40 . A control concrete (without POFA replacement) was also prepared for comparison purposes. This control concrete, hereinafter called OPS concrete consists of $480 \mathrm{~kg} / \mathrm{m}^{3}$ of cement, $192 \mathrm{~kg} / \mathrm{m}^{3}$ of water, $362 \mathrm{~kg} / \mathrm{m}^{3}$ of OPS and $820 \mathrm{~kg} / \mathrm{m}^{3}$ of river sand with a water to cement ratio 0.40 . After casting, all specimens were cured in a water tank for 28 days.

\section{B. Heating Regime of Concrete Specimens}

After being cured in water tank for 28 days, the concrete specimens were air dried in the laboratory for $20 \pm 4$ hours. After that, the concrete specimens were subjected to temperatures of $100^{\circ} \mathrm{C}, 200^{\circ} \mathrm{C}, 300^{\circ} \mathrm{C}, 400^{\circ} \mathrm{C}$ and $500^{\circ} \mathrm{C}$ in a muffle furnace. Once the targeted temperature was reached, concrete specimens were maintained in the furnace for 1 hour to achieve thermal steady state [13].

\section{Test Conducted}

After the specimens were subjected to elevated temperature, they were left to cool down for $20 \pm 4$ hours in room temperature before testing. Three tests were conducted to investigate the effects of elevated temperatures on the concrete specimens. These include visual inspection, mass loss, and compressive strength test. Visual inspections were done on the surface of concrete specimens to investigate the crack development on surface of the concrete specimens.

The mass of concrete specimens were recorded before and after the concrete specimens were subjected to elevated temperature. Then, the mass losses of concrete specimens were calculated using the formula:

$\mathrm{M}_{\mathrm{L}}=100 \times\left(\mathrm{M}_{1}-\mathrm{M}_{2}\right) / \mathrm{M}_{1}$

where $\mathrm{M}_{\mathrm{L}}$ is mass loss of concrete specimen; $\mathrm{M}_{1}$ is original mass recorded before heating $(\mathrm{g})$ and $\mathrm{M}_{2}$ is mass recorded after heating $(\mathrm{g})$.

Concrete specimens of $100 \mathrm{~mm} \times 100 \mathrm{~mm} \times 100 \mathrm{~mm}$ were used for compressive strength testing based on BS 1881: Part $116[14]$. 


\section{UNIMAS e-Journal of Civil Engineering}

\section{RESULTS AND DisCUSSIONS}

\section{A. Crack Development}

Each type of concrete experienced different patterns of crack when exposed to elevated temperatures. In this research, no cracks were observed on OPS concrete specimens at elevated temperatures of $100^{\circ} \mathrm{C}$ to $300^{\circ} \mathrm{C}$. However, some hair-line cracks were noticeable on the surface of OPS concrete specimens at temperatures of $400^{\circ} \mathrm{C}$ and $500^{\circ} \mathrm{C}$ as shown in Figure 1(a) and Figure 1(b) respectively. At a temperature of $400^{\circ} \mathrm{C}$, the slight amount of hair-lines cracks formed on the surface of OPS concrete specimens were much less visible compared to hair-line cracks formed at the elevated temperature of $500^{\circ} \mathrm{C}$. For POFA OPS concrete specimens, no cracks were found at elevated temperatures of $100^{\circ} \mathrm{C}$ to $400^{\circ} \mathrm{C}$. However, hair-line cracks were observed on the surface of the concrete at the temperature of $500^{\circ} \mathrm{C}$ which is shown in Figure 1 (c). It was observed that the hair-line cracks which formed on the surface of POFA OPS concrete specimens were less visible compared to hair-line cracks formed on the surface of OPS concrete specimens at elevated temperature of $500^{\circ} \mathrm{C}$. After cooling the concrete which has been subjected to elevated temperatures, the cracking observed was related to the rehydration of dissociated calcium hydroxide $\left(\mathrm{Ca}(\mathrm{OH})_{2}\right)$ [15]. It has been found that the $\mathrm{Ca}(\mathrm{OH})_{2}$ would dissociate after being subjected to elevated temperatures of $400^{\circ} \mathrm{C}$ to $600^{\circ} \mathrm{C}$ [15]. Due to the pozzolanic reaction in POFA OPS concrete, it is believed that there will be diminution of $\mathrm{Ca}(\mathrm{OH})_{2}$ from further hydration. Therefore, this could be the cause in the reduction of cracking when subjected to elevated temperature.

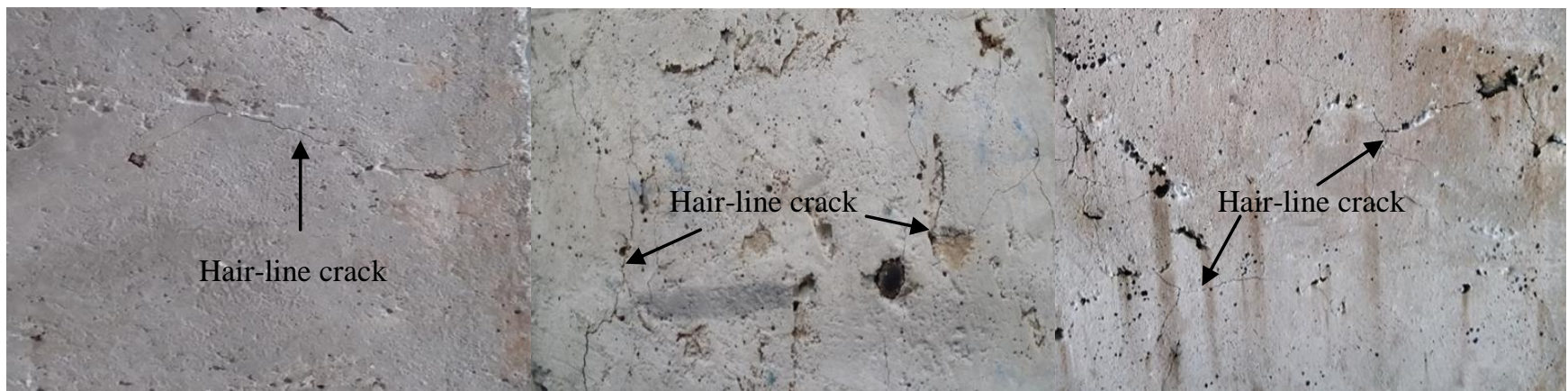

(a)

(b)

(c)

Figure 1: Hair-line cracks observed: (a) OPS concrete at temperature $400^{\circ} \mathrm{C}$; (b) OPS concrete at temperature $500^{\circ} \mathrm{C}$;

(c) POFA OPS concrete at temperature $500^{\circ} \mathrm{C}$

\section{B. Mass Loss}

The effect of elevated temperature on concrete mass loss was also investigated. Figure 2 shows the mass loss of concrete subjected to various temperatures. From the research, the OPS concrete specimens and POFA OPS concrete specimens experienced mass loss after heating. From the graph in Figure 2, it can be observed that the mass loss recorded for both concrete specimens increases when temperature increases. The mass loss was less significant at $100^{\circ} \mathrm{C}$ which were $1.63 \%$ and $1.66 \%$ for OPS and POFA OPS concrete specimen respectively. These results were in agreement with the research done by Siddique and Kaur [16], in which it was reported that free water is still retained in concrete when temperature reached $100^{\circ} \mathrm{C}$. However, beyond $100^{\circ} \mathrm{C}$, the OPS concrete specimens and POFA OPS concrete specimens showed significant mass loss with the increase in temperature. The largest mass loss recorded was $24.92 \%$ when heating temperature increase to $500^{\circ} \mathrm{C}$ for POFA OPS concrete specimens. This could be due to the greater water content held by porous POFA particles when subjected to elevated temperature of $500^{\circ} \mathrm{C}$ [13].

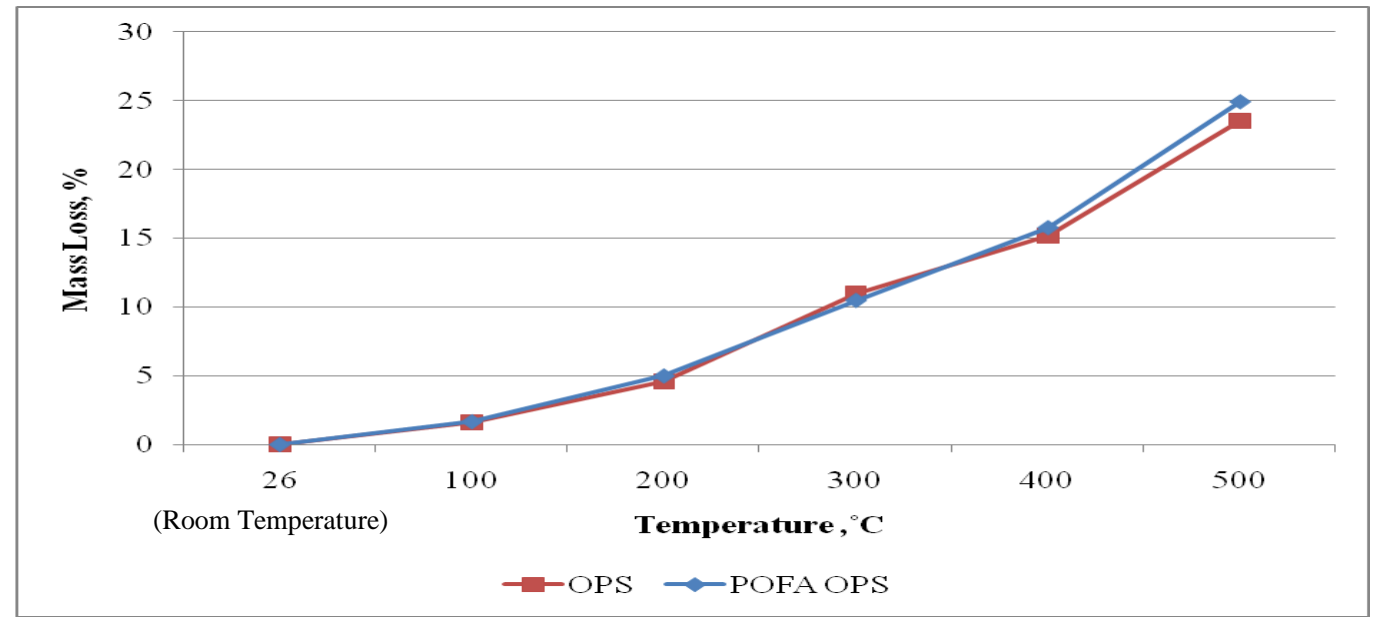

Figure 2: Mass loss of concretes subjected to various temperatures. 


\section{Compressive Strength}

The values of compressive strength recorded for all concrete specimens are presented in Figure 3. From Figure 3, the results showed there was a gradual decrease in compressive strength as the temperature increase for both specimens. There was a $74.18 \%$ decrease in strength for OPS concrete specimen, while for POFA OPS concrete specimen, there was a decrease of $64.15 \%$ in strength when the temperature increase from room temperature to $500^{\circ} \mathrm{C}$. A similar trend was observed by Ismail, Ismail and Muhammad [13] when POFA was integrated in the production of concrete. Hence, it can be shown that POFA OPS concrete showed better strength performance compared to OPS concrete when exposed to elevated temperatures.

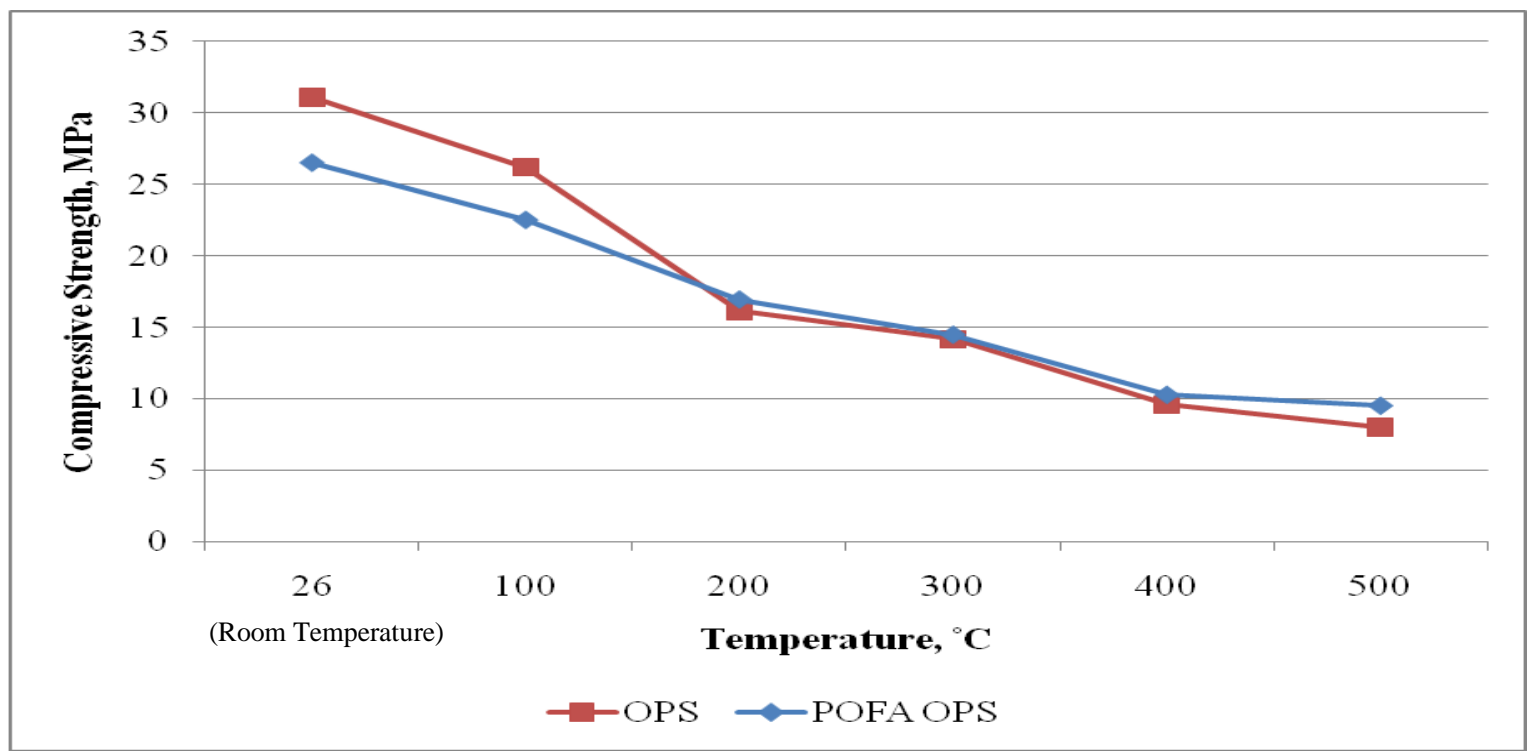

Figure 3: Compressive strength of concrete subjected to various temperatures.

\section{CONCLUSIONS}

Based on the results obtained from the current laboratory investigation, the following conclusions can be drawn:

i. Some hair-line cracks were noticed on the surface of OPS concrete specimens at temperatures of $400^{\circ} \mathrm{C}$ and $500^{\circ} \mathrm{C}$ and for POFA OPS concrete specimens, hair-line cracks were observed at a temperature of $500^{\circ} \mathrm{C}$. The hair-line cracks formed on the surface of POFA OPS concrete specimens were less visible compared to hair-line cracks which formed on the surface of OPS concrete specimens after being subjected to elevated temperature of $500^{\circ} \mathrm{C}$.

ii. The mass loss of concrete mass was less significant at $100^{\circ} \mathrm{C}$ for both OPS and POFA OPS concrete specimens. However, beyond $100^{\circ} \mathrm{C}$, both OPS and POFA OPS concrete specimens showed significant mass losses with the increase in temperature.

iii. The POFA OPS concrete specimens showed better strength performance as compared to OPS concrete specimens at the elevated temperatures of $200^{\circ} \mathrm{C}$ to $500^{\circ} \mathrm{C}$.

\section{REFERENCES}

[1] Z. Z. Ismail, and E. A. AL-Hashmi, "Use of waste plastic in concrete mixture as aggregate replacement," Waste Management, vol. 28, issue 11, pp. 2041- 2047, 2008.

[2] M. A. Mannan, J. Alexander, C. Ganapathy, and D. C. L. Teo, "Quality improvement of Oil Palm Shell (OPS) as coarse aggregate in lightweight concrete," Building and Environment, vol. 41, issue 9, pp. 1239-1242, 2006.

[3] W. Tangchirapat, C. Jaturapitakkul, and P. Chindaprasirt, "Use of palm oil fuel ash as a supplementary cementitious material for producing highstrength concrete," Construction and Building Materials, vol. 23, issue 7, pp. 2641-2646, 2009.

[4] A. Eldagal, and O. Elmukhtar, "Study on the behaviour of high strength Palm Oil Fuel Ash (POFA) concrete," Master Engineering Thesis (Civil and Structure), Universiti Teknologi Malaysia, 2008.

[5] M. A. Mannan, and C. Ganapathy, "Concrete from an agricultural waste Oil Palm Shell (OPS)," Building and Environment, vol. 39, issue 4, pp. 441$448,2004$.

[6] D. A. Crozier, and J. G. Sanjayan, "Chemical and physical degradation of concrete at elevated temperatures," Journal of the Concrete Institute of Australia, vol. 25, no. 1, pp. 18-20, 1999.

[7] J. G. Sanjayan, and L. J. Stocks, "Spalling of high-strength silica fume concrete in fire," American Concrete Institute Materials Journal, vol. 90, issue 2, pp. 170-173, 1993.

[8] M. S. Morsy, S. H. Alsayed, and M. Aqel, "Effect of elevated temperature on mechanical properties and microstructure of silica flour concrete," International Journal of Civil and Environmental Engineering, vol. 10, no. 1, pp. 1-6, 2010.

[9] R. Demirboğa, I. Türkmen, and M. B. Karakoç, "Thermo-mechanical properties of concrete containing high-volume mineral admixtures," Building and Environment, vol. 42, issue 1, pp. 349-354, 2007.

[10] S. Aydın, "Development of a high temperature resistant mortar by using slag and pumice," Fire Safety Journal, vol. 43, issue 8, pp. 610-617, 2008. 


\section{UNIMAS e-Journal of Civil Engineering}

[11] H. Y. Wang, "The effect of elevated temperature on cement paste containing ground granulated blast-furnace slag," Cement Concrete Research, vol. 30, issue 10, pp. 992-999, 2008.

[12] A. A. Ramezanianpour, M. Mahdikhani, and Gh. Ahmadibeni, "The effect of rice husk ash on mechanical properties and durability of sustainable concretes," International Journal of Civil Engineering, vol. 7, no. 2, pp. 83-91, 2009.

[13] M. Ismail, M. E. Ismail, and B. Muhammad, "Influence of elevated temperatures on physical and compressive strength properties of concrete containing palm oil fuel ash," Construction and Building Materials, vol. 25, issue 5, pp. 2358-2364, 2011.

[14] British Standard Institution. BS 1881-Part 116: 1983. Method for determination of compressive strength of concrete cubes. London: BSI, 1983.

[15] Y. Xu, Y. L. Wong, C. S. Poon, and M. Anson, "Impact of high temperature on PFA concrete," Cement and Concrete Research, vol. 31, issue 7, pp. 1065-1073, 2001.

[16] R. Siddique, and D. Kaur, "Properties of concrete containing ground granulated blast furnace slag (GGBFS) at elevated temperatures," Journal of Advanced Research, vol. 3, issue 1, pp. 45-51, 2012. 